\title{
溶融アルミニウムとアルミナの濡れと 反応に及ばす合金元素の影響
}

\author{
宮原広郁村岡隆二† \\ 森信幸 大城桂作 \\ 九州大学工学部材料工学科
}

J. Japan Inst. Metals, Vol. 59, No. 6 (1995), pp. 660-665

\section{Influence of Alloying Elements on Wettability and Reaction of Molten Aluminum with Alumina}

Hirofumi Miyahara, Ryuji Muraoka, Nobuyuki Mori and Keisaku Ogi

\section{Department of Materials Science and Engineering, Faculty of Engineering, Kyusyu University, Fukuoka}

\begin{abstract}
The effect of alloying elements on the wettability of molten aluminum to alumina substrate were investigated with the sessile drop method in a vacuum of $2 \times 10^{-3} \mathrm{~Pa}$ at temperatures from $973 \mathrm{~K}$ to $1173 \mathrm{~K}$.

The contact angle of molten aluminum on alumina substrate decreased from $109^{\circ}$ to $92^{\circ}$ as the temperature rose from $973 \mathrm{~K}$ to $1173 \mathrm{~K}$. The alloying elements of $5.5 \% \mathrm{Cu}, 15 \% \mathrm{Cu}, 33 \% \mathrm{Cu}, 1.1 \% \mathrm{Ni}, 6 \% \mathrm{Ni}, 10 \% \mathrm{Si}, 0.15 \% \mathrm{Ti}$, $0.17 \% \mathrm{Be}, 0.11 \% \mathrm{Zr}$ and $0.47 \% \mathrm{Hf}$ had little influence on the wettability to alumina. On the contrary, the addition of $4.1 \sim 9.7 \% \mathrm{Mg}$ and $1.7 \sim 4.2 \% \mathrm{Li}$ to molten aluminum lowered the contact angle by $10 \sim 20^{\circ}$. Higher the content of these elements more improved the wettability.

Both A1- $\mathrm{Li}$ and $\mathrm{Al}-\mathrm{Mg}$ alloys reacted with pure alumina in Ar atmosphere, and mass spectra and depth profile of positive secondary ions of $\mathrm{Al}^{+}, \mathrm{Li}^{+}, \mathrm{Mg}^{+}, \mathrm{O}^{+}, \mathrm{LiAl}^{+}, \mathrm{LiAlO}^{+}, \mathrm{MgAl}^{+}, \mathrm{MgO}^{+}$, etc. revealed that the $0.02 \sim 0.13$ $\mu \mathrm{m}$ thick $\mathrm{LiAlO}_{2}$ and $\mathrm{MgAl}_{2} \mathrm{O}_{4}$ were formed at the surface of alumina at $973 \mathrm{~K}$. The thickness of $\mathrm{LiAlO}_{2}$ layer increased proportionately to (reaction time $)^{1 / 2}$, the temperature and $\mathrm{Li}$ content, while the thin reaction layer of $\mathrm{MgAl}_{2} \mathrm{O}_{4}$ were almost unchanged even by longer holding until $3600 \mathrm{~s}$ at $1173 \mathrm{~K}$.
\end{abstract}

(Received November 21, 1994)

Keywords: wettability, contact angle, molten aluminum alloy, alumina, composites, reaction layer, positive secondary ion, mass spectra

\section{I．緒言}

金属溶湯を用いた複合材料の製造に执いては，溶融金属とセ ラミックスの需れ性が良いことが望まれる，通常の $\mathrm{Al}$ 合金鋳 造法での溶解温度近傍の $1023 \sim 1123 \mathrm{~K}$ では平滑な $\mathrm{Al}_{2} \mathrm{O}_{3}$ 基盤 に対する純 $\mathrm{Al}$ 溶湯の接触角は $90 \sim 120^{\circ}$ であり(1)-(3), さらに $\mathrm{Al}_{3} \mathrm{O}_{3}$ 基盤の表面が粗くなると濡れは大きく低下する(4)(5). 著 者らは 973 1173 K の減圧水素雾囲気で Ca の添加は濡れ性 を改善することを示した ${ }^{(6)}$ 。委た，長と沖(7)は $\mathrm{Al}_{2} \mathrm{O}_{3}$ と $\mathrm{Al}$ 合 金溶湯間での濡れの应がり速度に及济す合金元素の影響を系統 的に調查し，1273 K 保持で Ca, Ce, La の添加により濡れ性が 向上することを示している. 本研究では構造用 $\mathrm{Al}$ 合金の成分 元素として利用されている $\mathrm{Cu}, \mathrm{Mg}, \mathrm{Si}, \mathrm{Ni}, \mathrm{Li}$ ，さらに微量元 素の影響を調べる目的で $\mathrm{Be}, \mathrm{Fe}, \mathrm{Hf}, \mathrm{Ti}, \mathrm{Zr}$ を溶融 $\mathrm{Al}$ 亿添加 し, $\mathrm{Al}_{2} \mathrm{O}_{3}$ との濡れ性に及洔す各元素の影響を静滴法により調

$\dagger$ 九州大学大学院生
查した。また， $\mathrm{Mg}$ と $\mathrm{Li}$ を添加した合金に関しては， $\mathrm{Al}_{2} \mathrm{O}_{3}$ との反応実験を行い， $\mathrm{Al}_{2} \mathrm{O}_{3}$ 表面に生成した反応層の組成およ び結晶構造を調查した。

\section{II. 実験方法}

\section{1. 実験試料}

液滴用金属には，高純度 $\mathrm{Al}(99.99$ mass \% , 以下単位は mass\%とする)と $\mathrm{Cu}(99.9 \%), \mathrm{Mg}(99.9 \%), \mathrm{Si}(99.99 \%), \mathrm{Ni}$ $(99.9 \%), \mathrm{Fe}(99.9 \%), \mathrm{Hf}(95 \%), \mathrm{Zr}(99.6 \%), \mathrm{Al}-18.5 \% \mathrm{Li}$ 合金, $\mathrm{Al}-2.6 \% \mathrm{Be}$ 合金および $\mathrm{Al}-5.1 \% \mathrm{Ti}$ 合金を用いて所定の組成に 溶製した Al 合金を 0.5〜 $\mathrm{g}$ の立方体試片とし，アセトンで超 音波洗浄して用いた．固体基盤には，表面を鏡面仕上げした市 販の透光性高純度 $\mathrm{Al}_{2} \mathrm{O}_{3}$ 基盤（東芝セラミックス製 $\mathrm{TPA}-10$, 純度: $\mathrm{Al}_{2} \mathrm{O}_{3}>99.9 \%, \alpha-\mathrm{Al}_{2} \mathrm{O}_{3}$, 多結晶, 表面粗さ $\mathrm{R}_{\mathrm{a}}=0.05$ $\mu \mathrm{m})$ を $15 \mathrm{~mm} \times 15 \mathrm{~mm} \times 3 \mathrm{~mm}$ の板状試片とし，アセトンで 超音波洗浄した後，不純物の除去就よび基盤の安定化のため $1173 \mathrm{~K}, 2 \times 10^{-3} \mathrm{~Pa}$ で $3600 \mathrm{~s}$ 空焼さして用いた。 


\section{2. 実験装置および方法}

濡れ性測定実験は，液滴滴下装置を用いた静滴法に上り行っ た(8)。この液滴滴下装置は，黒鉛ピストンおよび黒鉛シリンダ 一に上り表面の酸化皮膜を破って液滴を押し出す方式であるた め，清浄な液滴を任意の温度拉よび時間で固体基盤上に滴下て きる. 真空炉内を $2 \sim 5 \times 10^{-3} \mathrm{~Pa}$ 程度 で真空排気した後に 昇温を開始 $し$, 約 $2 \times 10^{-3} \mathrm{~Pa}$ の真空度と $973 \mathrm{~K}$ おび 1073 $\mathrm{K}$ の測定温度に達した後, 液滴滴下装置により夜滴を基盤上 に静かに置いた，基盤の底面に接触させた PR 熱電対により湘 定温度を一定に保持しながら，液滴形状を $3600 \mathrm{~s}$ 吾で所定時 間ごとに撮影した．得られた写真の液滴形状执よび基盤表面を デジタイザーを用いてトレースし，Bashforth Adams ${ }^{(9)}$ に基つ いた曲線に当てはめ, その最適近似解から接触角, 液滴の表面 積拉上び表面張力を求めた。な特，最適近似解を求わる際に住 修正 Powell 法(10)を用いた。

最近, 著者らは溶融 $\mathrm{A} 1$ より酸化物生成標準自由エネルギー の低い $\mathrm{Ca}$ を添加した溶融 $\mathrm{Al}-\mathrm{Ca}$ 合金と $\mathrm{Al}_{2} \mathrm{O}_{3}$ 基盤の濡れ性を 調査したが，Ca の蒸気圧が $973 \mathrm{~K} て ゙ 16.0 \mathrm{~Pa}$ と極めて高いこ とから 270 670 Pa の減圧水素雾团気で本実験と同じ装置に より接触角を測定し，Caの添加により接触角は低下すること を明らかにした(6)。しかし，純 $\mathrm{Al}$ の接触角を比較した場合， 减圧水素雾围気での值は真空雾囲気の值 ${ }^{(3)}$ 上りもやや高く, 雾 囲気による差がみられた。そこで，蒸気圧の高い $\mathrm{Mg}$ 和よび Liを添加した合金に括いても，他の合金と同様に約 $2 \times 10^{-3}$ $\mathrm{Pa}$ の真空下飞゙実験した。なお，昇温中には酸化皮膜により溶 質元素の蒸発は妨げられ, 液滴滴下直前火打いても初期濃度を 維持していた.

次に，合金溶湯と $\mathrm{Al}_{2} \mathrm{O}_{3}$ の反応について調查したが， $\mathrm{Mg}$ 拉 よび $\mathrm{Li}$ 添加合金については，Mg および Li の蒸発を抑兄るた め，Ar 雾囲気で実験した，反応実験は濡れ性実験装置を用い， 炡内を $2 \sim 5 \times 10^{-3} \mathrm{~Pa}$ 程度まで真空排気した後に, 高純度 $\mathrm{Ar}$ で真空师内を置換し $1 \times 10^{5} \mathrm{~Pa} の \mathrm{Ar}$ 雲囲気にした. $1.5 \times$ $10^{-6} \mathrm{~m}^{3} / \mathrm{s}$ の $\mathrm{Ar}$ 気流中で昇温を開始し, 炉内が所定の温度 $(973 \mathrm{~K}, 1073 \mathrm{~K}$ 拈よび $1173 \mathrm{~K})$ に達した後, 液滴滴下装置に より液滴を基盤上に滴下させた。 $180 \mathrm{~s}, 600 \mathrm{~s}$ および $1200 \mathrm{~s}$ 保 持した後に割型炉を開いて空冷し, 約 $2 \mathrm{~K} / \mathrm{s}$ の速度で泠却さ せた凝固試料を作製した，試料は基盤上の液滴をエメリ一紙で 厚さ約 $10 \mu \mathrm{m}$ まで研磨した後 $6 \times 10^{3} \mathrm{~mol} / \mathrm{m}^{3}$ の塩酸で完全に 除去し, 純水扣よびアセトンで超音波洗浄後, 室温で十分乾燥 させた，得られた $\mathrm{Al}_{2} \mathrm{O}_{3}$ 基盤表面を検鏡するととるに，SIMS （日立製作所製 IMA-2AS 型 2 次イオン質量分析装置）を用い て質量数 1 から80までの各種の 2 次イオンの強度を浿定し， 基盤表層部を構成する元素の種類と結合状態を調查した.さら に, 1 次イオン $\left(\mathrm{Ar}^{+}\right)$で同一領域をスパッタし, 発生する 2 次 イオン ${ }^{27} \mathrm{Al}^{+},{ }^{7} \mathrm{Li}^{+},{ }^{26} \mathrm{Mg}^{+},{ }^{16} \mathrm{O}^{+}$等) の強度の变化から基盤の 表面からの深さ方向倿対する各元素の濃度変化を求めた。な特， SIMSによる分析では，まず $10 \mathrm{kV} て ゙$ 加速した $\mathrm{Ar}^{+} 1$ 次イ才 ンを $600 \mu \mathrm{m}$ のビーム径で基盤表面に照射し，スパッタリング によって試料から生じた 2 次イオンを $3 \mathrm{kV}$ の電場で引出し正 電磁場方式による二重収束型質量分析計(静電エネルギー分析 器执よび磁場型質量分析器の組合せ)により測定した。さらに，
$\mathrm{X}$ 線回折装置 (ターゲット: $\mathrm{Co}-\mathrm{K} \alpha$, 印加電圧 : $45 \mathrm{kV}$, フィ ラメント電流 : $120 \mathrm{~mA}$ )を用い, 薄膜の分析に有効な視斜角 入射法 ${ }^{(11)}$ によりX線入射角を $3^{\circ}$ K固定して $2 \theta=20 \sim 90^{\circ}$ の範 囲で走查させ，反応層の結晶構造を解析した。

\section{III. 実験結果および考察}

\section{1. $\mathrm{Al}_{2} \mathrm{O}_{3}$ 基盤に対する溶融 $\mathrm{Al}$ の需れ性に及ぼす各種元素 の影響}

Fig. 1 火 $973 \mathrm{~K}$ に抢ける $\mathrm{Al}_{2} \mathrm{O}_{3}$ 基盤に対する溶融 $\mathrm{Al}$ 合金の

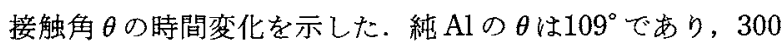
s变で变化はなかった． $\mathrm{Al}-10 \% \mathrm{Si}, 5.5 \% \mathrm{Cu}$ 叔よび $33 \% \mathrm{Cu}$ 合 金試料の $\theta$ は $106 \sim 110^{\circ}$ であり純 A1 の $\theta$ K近く, 時間依存性 も見られなかった。一方， A1-Li および $\mathrm{Al}-\mathrm{Mg}$ 合金試料では 液滴滴下值後で $92 \sim 102^{\circ}$ を示し，これらの元素の添加により 濡れ性が改善された。

また, $\mathrm{Li}, \mathrm{Mg}$ 添加合金では滴下後の時間経過に伴って $\theta$ が 若干低下し，A1-9.7\% $\mathrm{Mg}$ 合金試料では $30 \mathrm{~s}$ をでに $5^{\circ}, \mathrm{A} 1-4.2$ $\% \mathrm{Li}$ 合金試料では $\theta$ 岋 $120 \mathrm{~s}$ をで約 $2{ }^{\circ}$ 低下した。 そこで， $\theta$ の時間依存性を調査するため液滴形状の变化を観察した． Fig. 2 に $9.7 \% \mathrm{Mg}$ 試料について液滴と基盤の界面部の直径，液滴 の最大径および液滴の高さの経時変化を示したが，固液界面直 径が汪とんど変化していないのに対し, 液滴の高さ扣よび最大 径は時間の経過とともに低下し，液滴の体積は $30 \mathrm{~s}$ 後には $4.5 \mathrm{vol} \%$ 減少していた。 また，4.2\% Li 合金試料は $120 \mathrm{~s}$ 保持 で約 4 vol\%低下して特り，液滴の体積の減少が時間経過に伴 う接触角减少の一因であると考えられた。

$973 \mathrm{~K}$ に括いて，溶融純 Li 叔よび純 $\mathrm{Mg}$ の蒸気圧はそれぞ れ $53 \mathrm{~Pa}$ 抢よび $800 \mathrm{~Pa}$ と非常に高いため, Al-Li 招よび Al$\mathrm{Mg}$ 合金を真空中で高温保持すると $\mathrm{Li}, \mathrm{Mg}$ が蒸発していく. 原子量玉たは分子量 $M_{\mathrm{M}}$ の蒸発物質の高真空中での最大蒸発 速度 $V_{\max }\left(\mathrm{kg} /\left(\mathrm{m}^{2} \cdot \mathrm{s}\right)\right)$ は Langmuir の式(12)で与兄られ, 絶対 温度 $T(\mathrm{~K})$ K扣ける蒸気圧を $P_{M}(\mathrm{~Pa})$ とすると次式で示せる。

$$
V_{\max }=4.37 \times 10^{-3} \cdot \beta_{\mathrm{L}} \cdot P_{\mathrm{M}} \sqrt{\left(M_{\mathrm{M}} / T\right)}
$$

ただし $\beta_{\mathrm{L}}$ は“accomodation coefficient”と称するもので金属 原子のような無極性のものに対しては $\beta_{\mathrm{L}}=1$ となる.さらに，

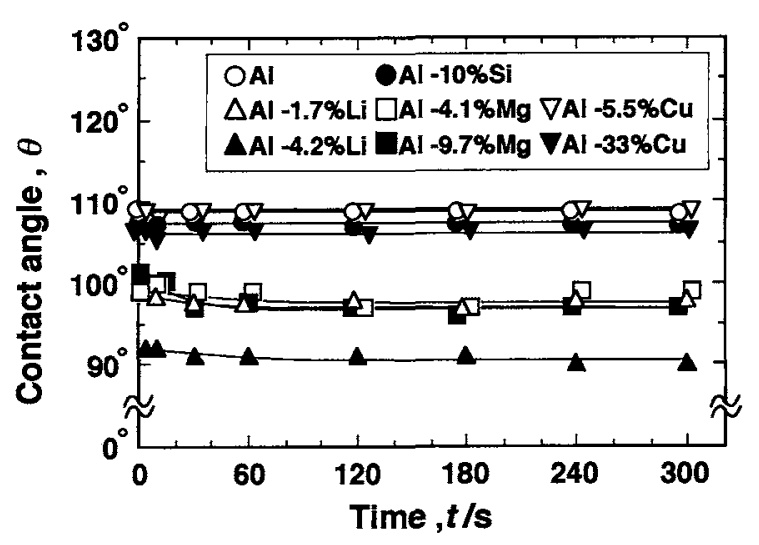

Fig. 1 Contact angle vs. time for molten $\mathrm{Al}$ alloys on $\mathrm{Al}_{2} \mathrm{O}_{3}$ substrate at $973 \mathrm{~K}$. 


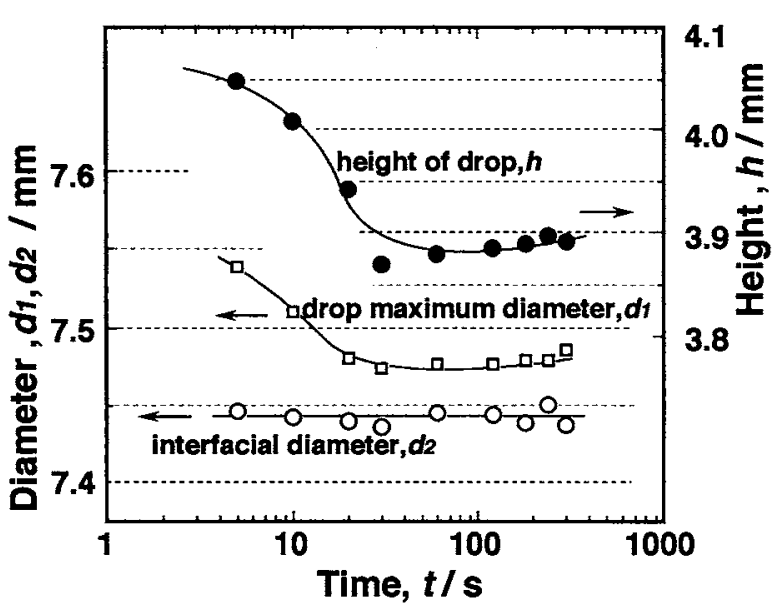

Fig. 2 Diameter of drop-substrate contact area, maximum diameter and height of drop for the Al-9.7 mass $\% \mathrm{Mg}$ alloy $/ \mathrm{Al}_{2} \mathrm{O}_{3}$ substrate system.

合金中の溶質元素の蒸発に関しては，その溶質単独の蒸気圧を $P_{\mathrm{M}}^{\circ}(\mathrm{Pa})$, 溶質元素の原子濃度比率を $N_{\mathrm{M}}$ とすると, Raoult の 法則を適用して $P_{\mathrm{M}}$ は次式で与允られる。

$$
P_{\mathrm{M}}=\gamma_{\mathrm{M}} \cdot N_{\mathrm{M}} \cdot P_{\mathrm{M}}^{\mathrm{o}}
$$

ここで, $\gamma_{\mathrm{M}}$ 恃活量俰数である。したがって，微小時間 $(d t)$ あ たりの蒸発量 $(d w / d t(\mathrm{~kg} / \mathrm{s}))$ は液滴の表面積 $S\left(\mathrm{~m}^{2}\right)$ を用いて次 式で示せる。

$d w / d t=4.37 \times 10^{-3} \cdot \beta_{\mathrm{L}} \cdot \gamma_{\mathrm{M}} \cdot P_{\mathrm{M}}^{\mathrm{o}} \cdot S \cdot \sqrt{\left(M_{\mathrm{M}} / T\right)} \cdot N_{\mathrm{M}}$

一方, 時間 $t=0 \mathrm{~s}$ での $\mathrm{Al}$ の筫量を $W_{\mathrm{Al}}(\mathrm{kg})$, 溶質元素の質量 を $W_{\mathrm{M}}(\mathrm{kg}), t$ 秒間で蒸発した溶質元素の質量を $W_{\mathrm{t}}(\mathrm{kg})$, 質量 分率を $[\mathrm{mass} \% \mathrm{M}]$ とすると, 活量の定義から以下の式が導か れる。

$$
d w / d t=\frac{\left(W_{\mathrm{A} 1}+W_{\mathrm{M}}-W_{\mathrm{t}}\right)}{100} \cdot \frac{d[\mathrm{mass} \% \mathrm{M}]}{d t}
$$

また, 時間 $t$ 秒後の夜滴の質量と溶質の質量分率の関係は次式 で示せる。

$$
\left(W_{\mathrm{Al}}+W_{\mathrm{M}}-W_{\mathrm{t}}\right)=\frac{W_{\mathrm{A} 1}}{1-\frac{[\mathrm{mass} \% \mathrm{M}]}{100}}
$$

したがって，式(3)〜（5)より

$\frac{d[\text { mass } \% \mathrm{M}]}{d t}=\frac{4.37 \times 10^{-3} \cdot \beta_{\mathrm{L}} \cdot \gamma_{\mathrm{M}} \cdot P_{\mathrm{M}}^{\circ} \cdot S \cdot \sqrt{\left(M_{\mathrm{M}} / T\right)}}{W_{\mathrm{A} 1}}$

$$
\times\left(\frac{(100-[\mathrm{mass} \% \mathrm{M}]) \cdot \frac{[\text { mass } \% \mathrm{M}]}{M_{\mathrm{M}}}}{\frac{[\mathrm{mass} \% \mathrm{M}]}{M_{\mathrm{M}}}+\frac{100-[\mathrm{mass} \% \mathrm{M}]}{M_{\mathrm{AI}}}}\right)
$$

ここで， $M_{\mathrm{M}}, M_{\mathrm{Al}}$ は溶質元素和よび $\mathrm{A} 1$ の原子量である， $\gamma_{\mathrm{M}}$

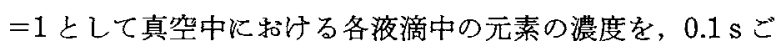
とに数值積分した結果をFig. 3 に実線で示した. Fig. 3 より， 液滴中の $\mathrm{Mg}$ は約 $20 \mathrm{~s}$ で汪とんどなくなり，Li は約 $200 \mathrm{~s} て ゙$ $0.1 \%$ 以下となった。これ火対して，液滴試料中の $\mathrm{Mg}$ 和よび Li 濃度をEPMA および IMA を用いて測定した結果, A1-9.7 $\% \mathrm{Mg}$ 試料の $\mathrm{Mg}$ 濃度は $60 \mathrm{~s}$ 保持で $0.08 \%$ をで減少し, Al- 1.7 $\% \mathrm{Li}$ 拉よび $4.5 \% \mathrm{Li}$ 試料では $300 \mathrm{~s}$ 保持で $\mathrm{Li}$ 濃度はそれぞれ

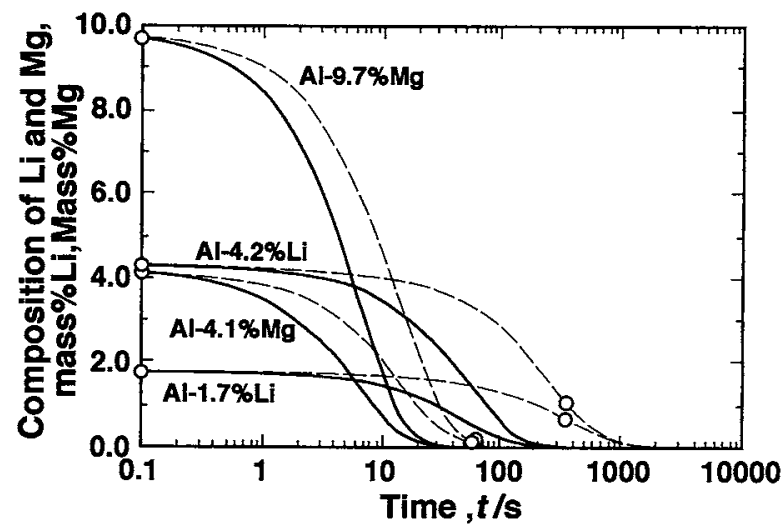

Fig. 3 Changes in $\mathrm{Li}$ and $\mathrm{Mg}$ contents of $\mathrm{Al}$ alloy drops.

$0.65 \%, 1.06 \%$ まで減少していた，実䁚值との差は $\gamma_{\mathrm{M}}=1$ と仮 定したことと，液滴表面の酸化皮膜などが影響したことなどが 考兄られ， $\gamma_{\mathrm{M}}, \beta$ および表面の酸化皮膜の影響を含めた補正係 数を $\alpha$ として式(6)に導入し，湘定值に当てはまるように $\alpha$ を決定してFig. 3 中に破線で示した。これより任意の時間で の Li および Mg の濃度が予測でき，その蒸発過程は Fig. 2 の 夜滴形状の経時変化とよく対応した，以上から明らかに，接触 角の経時変化は主として $\mathrm{Mg}$ 和よび $\mathrm{Li}$ の蒸発によるものであ り，蒸発の影響を除外するためにはでさるだけ短時間での測定 值が望ましく，Al-Mg 拉よび Al- $\mathrm{Li}$ 系試料に限り，滴下した 液滴の振動が完全に収をる $5 \mathrm{~s}$ 保持の值を採用した。したがっ て，Al-Li 試料および Al-Mg 試料では，それぞれ合金元素が 添加量の97\%以上拈よび65\%以上残存する液滴と $\mathrm{Al}_{2} \mathrm{O}_{3}$ 基盤 との需れ性の評価となる。また，5 $\mathrm{s}$ 保持では反層は忹とん ど生じていないと考えられるが，予備実験として Ar䨌囲気で も需れ性を測定しており，十分反応が生じていると考元られる 長時間保持でも接触角の経時変化は見られず， $\mathrm{Al}-\mathrm{Mg}$ 抌よび $\mathrm{Al}-\mathrm{Li}$ 系試料では反度層の生成による需れ性への影響は小さい と考兄られた。なお，Mgおよび Li が蒸発した $300 \mathrm{~s}$ 保持後 でも接触角は依然として $90 \sim 100^{\circ}$ の值を維持している。これ は，後述するよ5K比較的短時間保持でも $\mathrm{Al}_{2} \mathrm{O}_{3}$ 基盤表層部 に反店層が生成し，表面性状が変化したことや吉見ら ${ }^{(13)}$ む指 摘しているょうに, 溶質元素の蒸発後に接触角が溶融 $\mathrm{A} 1$ の後 退接触角を維持していることなどが考克られる。

従来の実験結果と比較するため $300 \mathrm{~s}$ 保持の值，また Al-4.2 $\% \mathrm{Li}$ および $9.7 \% \mathrm{Mg}$ 合金については, $5 \mathrm{~s}$ 保持の值も併せて， 温度との関係をFig. 4 に示した，濡れ性に及ぼす微量元素の 影響を調查することを目的とした $\mathrm{Al}-0.15 \% \mathrm{Ti}, 0.17 \% \mathrm{Be}, 0.11$ $\% \mathrm{Zr}$ 扎よ゙ $0.47 \% \mathrm{Hf} よ り 反$ 応性が高いと思われる $1073 \mathrm{~K}$ 保持で行った値も示した. 純 $\mathrm{A} 1$ との接触角は $973 \mathrm{~K}$ 保持で約 $110^{\circ}$ を示し，温度の上昇とともに低下し，1173 K 保持では $92^{\circ}$ を示した。この $\theta$ は Brennan と Pask ${ }^{(1)}$ や Prabriputaloong と Piggott ${ }^{(2)}$ の文献値とほぼ同様の值である．構造用合金とし て用いられる元素を添加したA1-1.1\% $\mathrm{Ni} ， 6 \% \mathrm{Ni}, 5.5 \% \mathrm{Cu}, 10$ $\% \mathrm{Si} ，$ さらに酸化物生成自由エネルギーの低い元素を微量添加 した $\mathrm{Al}-0.17 \% \mathrm{Be}, 0.15 \% \mathrm{Ti}, 0.47 \% \mathrm{Hf}, 0.11 \% \mathrm{Zr}$ 合金の接触角 は 973 1073 K 保持で106〜113を示し，いずれの元素も濡 


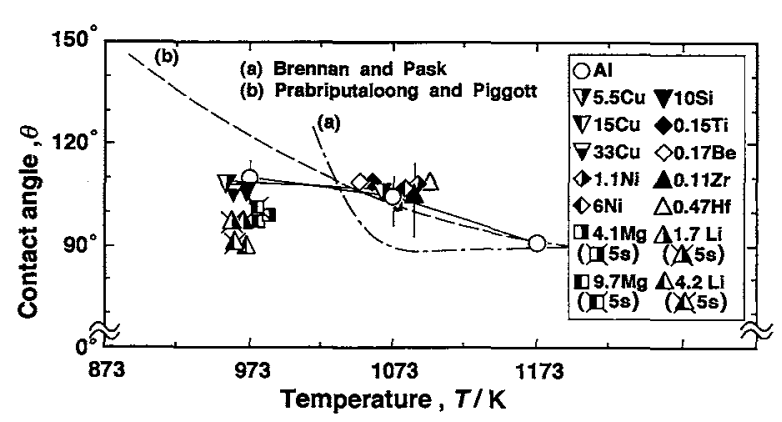

Fig. 4 Contact angle vs. temperature for molten $\mathrm{Al}$ alloys on $\mathrm{Al}_{2} \mathrm{O}_{3}$ substrate. Holding time is $5 \mathrm{~s}(\mathbf{\pi}, \mathbf{Z}, \not{\alpha}, \mathbf{Z})$ or $300 \mathrm{~s}$ (other symbols).

れ性改善効果は忹とんど見られなかった。一方，前述したよう に $\mathrm{Li}$ と $\mathrm{Mg}$ はわずかであるが濡れ性を改善した。純 $\mathrm{Al}$ の接 触角に対して Al-Li 和よび $\mathrm{Mg}$ 合金の值は液滴滴下直後からす でに 7 1 $7^{\circ}$ 低く，先の後の蒸発に上る見掛けの接触角の低下 は $2 \sim 5^{\circ}$ と小さいことから，濡れ性の改善には主として元素の 添加が寄与するものと考党られる.

合金元素の添加による液体の表面張力の变化は一般に液滴中 の溶質元素が液体の表面に吸着されるために生じ，このときの 表面に集まる過剩な原子の濃度は Gibbs ${ }^{(14)}$ の吸着式に上り得

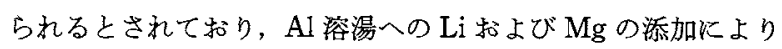
溶融 $\mathrm{A} 1$ の表面エネルギー(気液界面エネルギー) $\gamma_{\mathrm{lv}}$ が低下する ことがLangにより示されている(15)(16). また， $\mathrm{Al}_{2} \mathrm{O}_{3}$ の表面

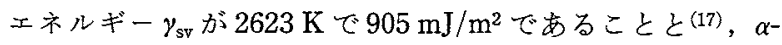
$\mathrm{Al}_{2} \mathrm{O}_{3}$ の (0001) 面の表面エネルギーは温度が $1 \mathrm{~K}$ 佂下すると $0.12 \mathrm{~mJ} / \mathrm{m}^{2}$ 增加すること(18) から $973 \mathrm{~K}$ に打りる值を $\gamma_{\mathrm{sv}}=$ $1000 \sim 1100 \mathrm{~mJ} / \mathrm{m}^{2}$ と仮定寸ると， $\mathrm{Al}$ 合金と $\mathrm{Al}_{2} \mathrm{O}_{3}$ との界面 ×ネルギー $\gamma_{\mathrm{ls}}$ は, Young-Dupré(19)の式

$$
\gamma_{\mathrm{sv}}=\gamma_{\mathrm{ls}}+\gamma_{\mathrm{lv}} \cos \theta
$$

から求めることができる。本実験の場合には， $\mathrm{Al}_{2} \mathrm{O}_{3}$ と溶融 $\mathrm{Al}-9.6 \% \mathrm{Mg}$ 合金の界面エネルギーは 1134〜 $1234 \mathrm{~mJ} / \mathrm{m}^{2}$ とな り, 溶融純 $\mathrm{Al}$ との界面エネルギー $\left(1277 \sim 1377 \mathrm{~mJ} / \mathrm{m}^{2}\right)$ 上り も低い、主なわち， $\mathrm{Li}$ および $\mathrm{Mg}$ は $\mathrm{Al}$ 液滴の表面エネルギー を低下させるが， $\mathrm{Al}_{2} \mathrm{O}_{3}$ との固液界面エネルギ一も下げるた め，濡れ性が向上したものと考えられる．溶融金属と $\mathrm{Al}_{2} \mathrm{O}_{3}$ との濡れ性については, MacDonald と Eberhart ${ }^{(20)} か ゙ \mathrm{Al}_{2} \mathrm{O}_{3}$ との需れ性は金属の酸化物形成の標準エネルギーに比例して大 きくなることを示しており，野城と荻野(21)は $\mathrm{Al}_{2} \mathrm{O}_{3}$ 表面で分 極したイオンの半径が固液界面張力に影響すると指摘して和 り，さらに，長と沖 ${ }^{(7)}$ は溶融 $\mathrm{A} 1$ 中の酸素溶解度を上昇させる 元素の泒加が有効であるとしている. 濡れ性改善の機構につい ては未だ結論は得られていないが, $\mathrm{Al}_{2} \mathrm{O}_{3}$ 最表面がイオン半径 の大きい酸素で覆われている(22)ことと, $1273 \mathrm{~K}$ の高温, 真空 䨌团気になると $\mathrm{Al}_{2} \mathrm{O}_{3}$ 表面は $\mathrm{Al}_{2} \mathrm{O}$ や $\mathrm{AlO}$ などの酸素欠乏相 により覆われ(23)， $\mathrm{Al}_{2} \mathrm{O}_{3}$ 基盤の表面エネルギーが增加して濡 れ性が改善されることなどから，濡れ性に及ぼす合金元素の影 響を考える場合, $\mathrm{Al}_{2} \mathrm{O}_{3}$ 表面の酸素との関保が最も重要である

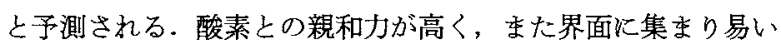
$\mathrm{Li}$ 捛よび $\mathrm{Mg}$ 等の元素が界面エネルギーを下げるとともに，
その元素の酸化物形成能が $\mathrm{Al}$ より高い場合には $\mathrm{Al}_{2} \mathrm{O}_{3}$ 表層部 に酸化物を形成するものと推測される。

\section{2. $\mathrm{Al}_{2} \mathrm{O}_{3}$ と溶融 $\mathrm{Al}-\mathrm{Li}$ および $\mathrm{Al}-\mathrm{Mg}$ 合金との反応}

$\mathrm{Li}$ およ゙ $\mathrm{Mg}$ は酸化物形成能が $\mathrm{Al}$ 上り高く $\mathrm{Al}_{2} \mathrm{O}_{3}$ との反応 層の生成が予測されるが, 前述の上らに真空雲囲気では $\mathrm{Mg}$ 拈よび Li が蒸発するため界面反应層の生成等の界面での元素 の挙動を定量的に把握することは困難之考兄られた。 したがっ て，溶質元素の蒸発を掤えるため $1 \times 10^{5} \mathrm{~Pa} の \mathrm{Ar}$ 雲用気で同 じ装置を用いて $\mathrm{Al}_{2} \mathrm{O}_{3}$ 基盤と接触実験を行った. $\mathrm{Al}-3.2 \% \mathrm{Li}$ および $5.8 \% \mathrm{Mg}$ 合金融液と $\mathrm{Al}_{2} \mathrm{O}_{3}$ を $973 \mathrm{~K}$ で $180 \sim 1200 \mathrm{~s}$ 接 触させた後，液滴を除去して基艎表面を観察したところ，液滴 と接していた領域は変色し基盤表面の性状が変化したことが認 められた。 そこで, SIMSを用いて各基盤表面をスパッタし, 得られた 2 次イオンマススペクトルから基盤表層部を構成す

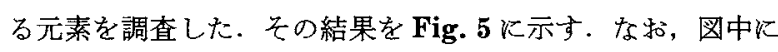
は比較のため末反応の $\mathrm{Al}_{2} \mathrm{O}_{3}$ 基盤からの 2 次イオンマススぺ クトルも示した．図(a)の $\mathrm{Li}$ 合金試料の場合，図(c)の $\mathrm{Al}_{2} \mathrm{O}_{3}$ 基盤のマススペクトルに認められない質量数 6,7 の $\mathrm{Li}^{+}$単原 子イオンや質量数 33,34 のiAl $\mathrm{Li}^{+}$，質量数 50 の $\mathrm{LiAl}^{+}$などの 分子イオンが検出されて招り，Liを含も反応生成物の存在が 推定された。図(b) は溶融 $\mathrm{Al}-\mathrm{Mg}$ 合金之 $\mathrm{Al}_{2} \mathrm{O}_{3}$ との界面反応 層について測定した結果である．未反応のアルミナ基盤中に微 量の $\mathrm{Mg}$ が不純物として含まれているため, 反応層と $\mathrm{Al}_{2} \mathrm{O}_{3}$ 基盤の 2 次イオンマススペクトルは類似しているが， ${ }^{24} \mathrm{Mg}^{+}$ イオン強度は反応層の方が著しく高く, さらに $\mathrm{Mg}^{2+}, \mathrm{MgO}^{+}$, $\mathrm{MgAl}^{+}$等の 2 次イオン名検出された. Al-Li 合金, Al-Mg 合 金のいずれの場合す，反応層からの2次イオンマススペクト ルは接触時間によらず類似して和り，接触の初期段階から同じ 化合物が生成していると判断された。そこで $1200 \mathrm{~s}$ 保持した 試料の反応層を視斜角入射 $\mathrm{X}$ 線回析法により調査したところ,

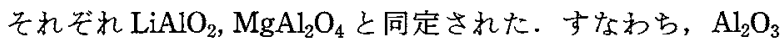

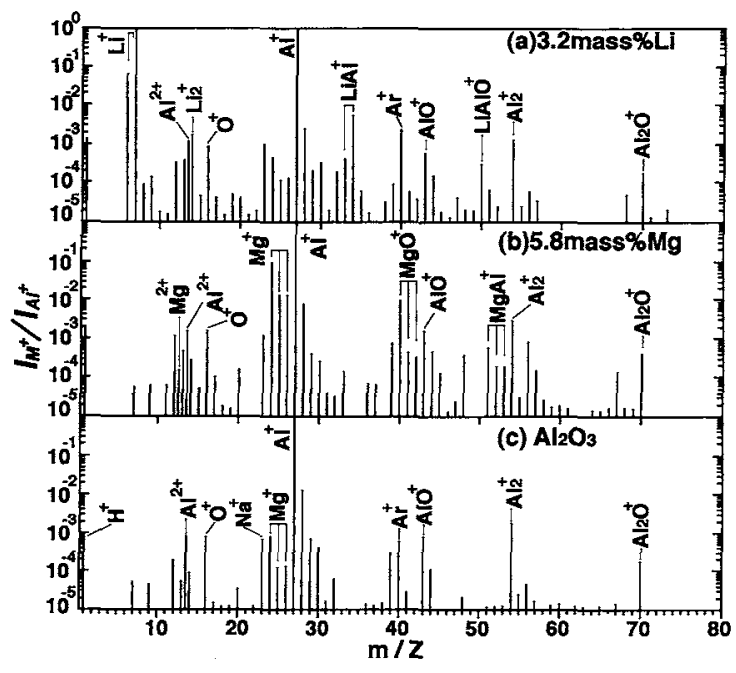

Fig. 5 Positive secondary ion mass spectra of reaction layer between molten Al-3.2 mass\% $\%$ Li(a) or Al-5.8 mass $\% \mathrm{Mg}(\mathrm{b})$ and $\mathrm{Al}_{2} \mathrm{O}_{3}$ held at $973 \mathrm{~K}$ for $1200 \mathrm{~s}$, and those of $\mathrm{Al}_{2} \mathrm{O}_{3}$ substrate (c). 


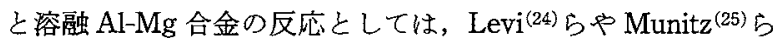
も指摘しているように式(8)で示される反応が，また，溶融 Al-Li 合金炕つて 式 (9)で示される Likよる $\mathrm{Al}_{2} \mathrm{O}_{3}$ の還 元反応が考えられる.

$$
\begin{aligned}
& 3 \mathrm{Mg}+4 \mathrm{Al}_{2} \mathrm{O}_{3}=3 \mathrm{MgAl}_{2} \mathrm{O}_{4}+2 \mathrm{Al} \\
& 3 \mathrm{Li}+2 \mathrm{Al}_{2} \mathrm{O}_{3}=3 \mathrm{LiAlO}_{2}+\mathrm{Al}
\end{aligned}
$$

次にこれらの反応生成物の成長挙動について調查するため, SIMSによる深さ方向分析を行った．Fig. 6 に各試料の基盤 表面から深さ方向に対して ${ }^{27} \mathrm{Al}^{+},{ }^{7} \mathrm{Li}^{+},{ }^{24} \mathrm{Mg}^{+}$拉よび ${ }^{16} \mathrm{O}^{+}$の 2 次イオン強度を分析した結果を示す. 図の綖軸は, 各 2 次イ オンの電流強度 $I$ を構成元素の全 2 次イオン強度で規格化した わので，相対的な濃度変化を見ることがでさる。また，横軸の スパッタ深さは，あらかじめ各試料についてスパッタしたクレ ーターの深さを精密表面粗さ計（タリステップ）により測定して スパッタ速度として $0.08 \mathrm{~nm} / \mathrm{s}$ 得て拈り，分析時のスパッ タ時間から換算した．図(a)の Al-Li 合金試料の場合, $180 \mathrm{~s}$ 保 持試料では ${ }^{7} \mathrm{Li}^{+}$インの強度は基盤表層部で高い值を示し， 一方, ${ }^{27} \mathrm{Al}^{+}$イオン強度は表層部で低く, 次第にバルクの強度 に近づいている，これらの2次イオン強度プロファイルから 生成した $\mathrm{LiAlO}_{2}$ の厚さは約 $0.05 \mu \mathrm{m}$ であると判断される。 ま た， $1200 \mathrm{~s}$ 保持試料では反応層の厚さが約 $0.13 \mu \mathrm{m}$ に増して いる. Al- $\mathrm{Mg}$ 合金試料の場合も， ${ }^{24} \mathrm{Mg}^{+}$イオン強度プロフ イルから，180 s 保持では $\mathrm{MgAl}_{2} \mathrm{O}_{4}$ は $0.02 \sim 0.03 \mu \mathrm{m}$ である。 これらのSIMS 分析結果から得られた反応層の厚さと保持時

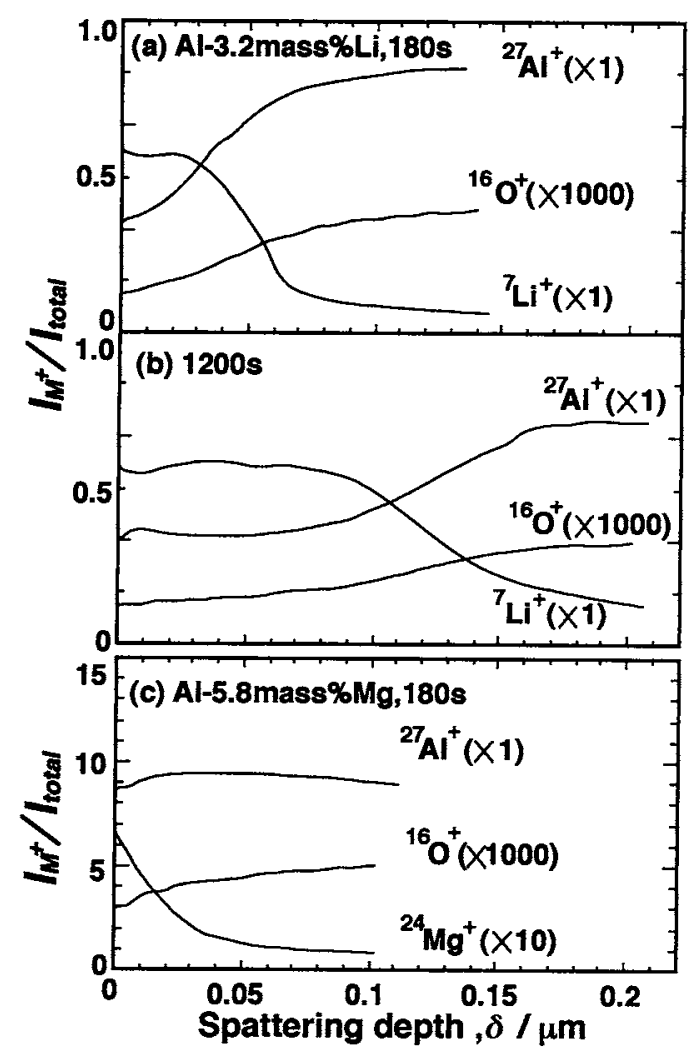

Fig. 6 Depth profiles of secondary ion intensity in reaction layers of $\mathrm{Al}_{2} \mathrm{O}_{3}$ substrate formed with $\mathrm{Al}-3.2$ mass\% $\mathrm{Li}(\mathrm{a}, \mathrm{b})$ and $\mathrm{Al}-5.8$ mass $\% \mathrm{Mg}(\mathrm{c})$ alloys at $973 \mathrm{~K}$.
間の関係をFig.7亿示した.なお，反応層とバルク層との境 界部において2次イオン強度は深さ方向に対して滑らかに变 化しているため，反応層厚さの決定が困難であった：この原因 としてスパッタ表面に四凸が生じることなどが考完られるが， 反応層の 2 次イオン強度が変化し始める位置およびバルク材 の強度を示す位置をェラーバーの端部の値で示し，その間の 2 次イオン強度の平均值を示すスパッ夕深さを○印で示した。 $\mathrm{LiAlO}_{2}$ 層の厚さは時間の注济 $1 / 2$ 乗に比例して增加して招 り， $\mathrm{LiAlO}_{2}$ の成長は反应層内での物質移動に律速されるもの と考えられる。孚た，Al-Li 合金試料について保持温度 $T(\mathrm{~K})$ を上昇させた場合，Fig. 8 亿示すよ 5 K $\mathrm{LiAlO}_{2}$ の厚さ $\delta(\mu \mathrm{m})$ は増加し，973〜 $1173 \mathrm{~K}$ の温度範囲では次式により示される 直線関係が得らえた。

$$
\delta=4.36 \times 10^{-4}(T-973)+0.11
$$

さらに，合金中の $\mathrm{Li}$ 濃度と反底層の厚さの関係を $973 \mathrm{~K}$ で調 查した結果をFig.9に示した，因より Li 濃度が約 $5 \%$ 以下で は反応層の厚さは $\mathrm{Li}$ 濃度の上昇ととるにほ洼直線的に増加す ることが確認された。一方, $\mathrm{MgAl}_{2} \mathrm{O}_{4}$ の場合は, Fig. 7 亿示 すよらに時間が経過しても一定の值を維持している.さらに， $\mathrm{Al}-9.7 \% \mathrm{Mg}$ 合金をより反応性が高いと思われる $1173 \mathrm{~K} て ゙$ て接 触させた実験を行ったが，3600 s 保持しても反应層の厚さは

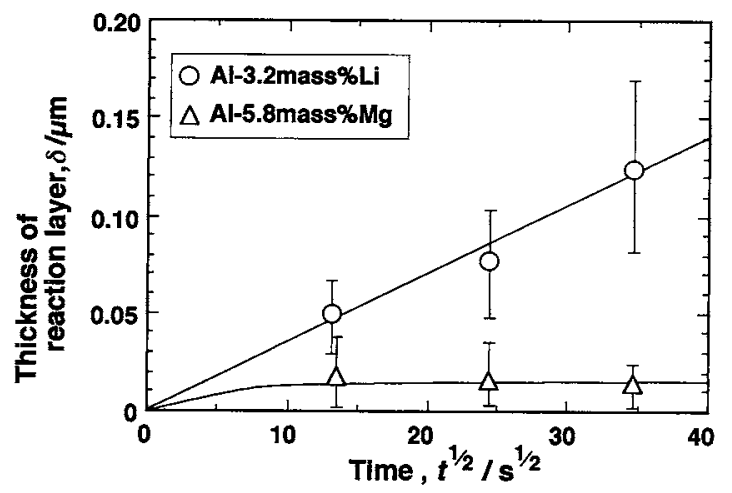

Fig. 7 Growth of reaction layers between molten $\mathrm{Al}$ alloys and $\mathrm{Al}_{2} \mathrm{O}_{3}$ substrate at $973 \mathrm{~K}$.

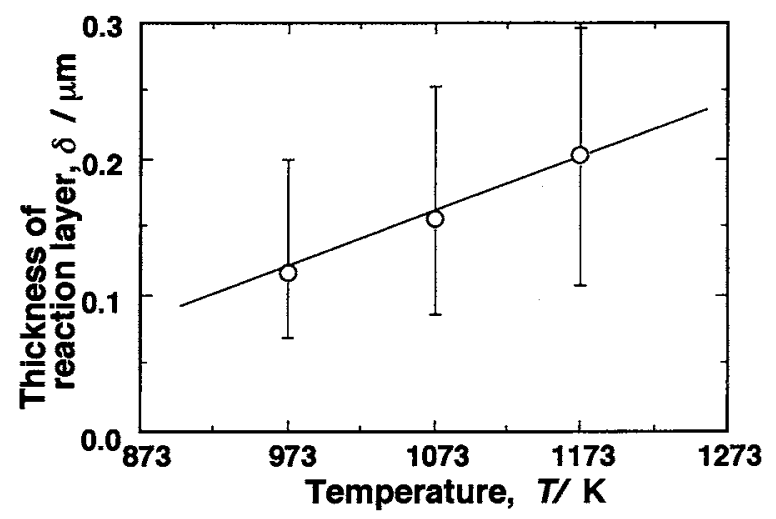

Fig. 8 Thickness of reaction layer vs. temperature for molten $\mathrm{Al}-4.2$ mass $\% \mathrm{Li}$ alloy on the $\mathrm{Al}_{2} \mathrm{O}_{3}$ substrate. The reaction time is $600 \mathrm{~s}$. 


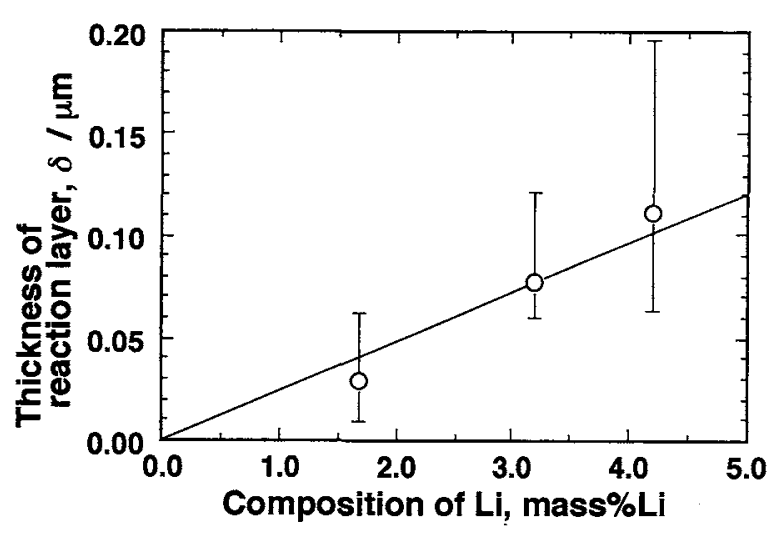

Fig. 9 Thickness of reaction layer vs. Li content of molten $\mathrm{Al}-\mathrm{Li}$ alloy on the $\mathrm{Al}_{2} \mathrm{O}_{3}$ substrate, at $973 \mathrm{~K}$ for $600 \mathrm{~s}$.

約 $0.03 \mu \mathrm{m}$ であった。すなわ方 $\mathrm{Al}-5.8 \sim 9.7 \% \mathrm{Mg}$ の組成の融 液を973 1173 K で $180 \sim 3600 \mathrm{~s}$ 間, $\mathrm{Al}_{2} \mathrm{O}_{3}$ 亡接触させた場 合には表層部に薄い $\mathrm{MgAl}_{2} \mathrm{O}_{4}$ が生成されるが，反応層の厚さ は時間，組成および保持温度には庄とんど影響されず，ほぽ一 定の值を示す．この原因として，生成された $\mathrm{MgAl}_{2} \mathrm{O}_{4}$ の形態 と $\mathrm{MgAl}_{2} \mathrm{O}_{4}$ 中を昖散する各イオンの速度が考兄られる。溶融 $\mathrm{Al}-\mathrm{Mg}$ 合金と $\mathrm{Al}_{2} \mathrm{O}_{3}$ の界面珄じる $\mathrm{MgAl}_{2} \mathrm{O}_{4}$ の生成について は Jin とLloyd (26)の報告があり， $\mathrm{Al}$ 合金中の $\mathrm{Mg}$ 濃度が $3 \%$ 以下では $\mathrm{MgAl}_{2} \mathrm{O}_{4}$ は不均一飞生成し, $\mathrm{MgAl}_{2} \mathrm{O}_{4}$ は隙間から供 給される元素により粗大に成長するが， $3 \% \mathrm{Mg}$ 以上になると 緻密な $\mathrm{MgAl}_{2} \mathrm{O}_{4}$ が連続的に界面に生成し，その後の成長は停 止するとしている，本実験の組成は後者偊して特り，同様の 現象が生じたもの々考兄られる。また，この時生成された $\mathrm{MgAl}_{2} \mathrm{O}_{4}$ はスピネル型の構造を持つが，反応層中を移動する 各原子は, 各原子およびサイトの濃度勾配等を駆動力として, 単位格子内の電気的バランスを保ちながら同種類の最隣接サイ トのみを移動するので金属の場合より遅いとされている(27). $\mathrm{MgAl}_{2} \mathrm{O}_{4}$ 単結晶中の $\mathrm{Mg}$ 拈よび $\mathrm{O} の$ 桩散係数が $1705 \mathrm{~K}$ 亿括

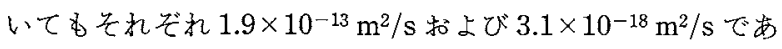
り ${ }^{(28)}$ ，反応初期で緻密な $\mathrm{MgAl}_{2} \mathrm{O}_{4}$ 相が生成したため，その後 の反応は医とんど進行しなかったものと考克られる。

\section{N. 結 言}

$\mathrm{Al}_{2} \mathrm{O}_{3}$ と溶融 $\mathrm{Al}$ との濡れ性执よび反応に及淁す各種の合金 元素の影響を調査し, 以下の結論を得た。

(1) $\mathrm{Al}_{2} \mathrm{O}_{3}$ K対する溶融 $\mathrm{Al}$ の接触角 $\theta$ は, 保持温度が 973 $\mathrm{K}$ から $1173 \mathrm{~K}$ 一上昇すると, $109^{\circ}$ から $92^{\circ}$ 一低下した。 Al$4.1 \sim 9.7 \% \mathrm{Mg}, \mathrm{Al}-1.7 \sim 4.2 \% \mathrm{Li}$ 合金では, $973 \mathrm{~K}$ でいずれる 92 102 へ低下し, 各元素の添加量を増す汪に゙需れ性が改善 された.これは添加元素による $\mathrm{Al}$ 合金 $/ \mathrm{Al}_{2} \mathrm{O}_{3}$ 界面エネルギー の低下が寄与するものと考光られた。

（2）溶融 $\mathrm{Al}-\mathrm{Li}$ 扣よび $\mathrm{Al}-\mathrm{Mg}$ 合金と $\mathrm{Al}_{2} \mathrm{O}_{3}$ を接触さ好ると
界面にそれぞれ $\mathrm{LiAlO}_{2}, \mathrm{MgAl}_{2} \mathrm{O}_{4}$ が生成された。 $\mathrm{LiAlO}_{2}$ 層の 厚さは時間の平方根，保持温度竹よび Li 濃度に比例して増加 したが，緻密に生成した $\mathrm{MgAl}_{2} \mathrm{O}_{4}$ 層は保持温度和よび時間に 上らず一定の厚さを保持した.

(3) 溶融 $\mathrm{Al}$ への5.5\% Cu, $15 \% \mathrm{Cu}, 33 \% \mathrm{Cu}, 1.1 \% \mathrm{Ni}, 6 \% \mathrm{Ni}$, $10 \% \mathrm{Si}, 0.15 \% \mathrm{Ti}, 0.17 \% \mathrm{Be}, 0.11 \% \mathrm{Zr}, 0.47 \% \mathrm{Hf}$ の添加は本実 験の条件では濡れ性に影響を及ぼさなかった。

終わりに，反応層牤よび液滴試料の定量分析は九州大学工学 部IMA 実験室の EPMA 扣よび IMA 装置を利用したことを付 記します。

$$
\text { 文献 }
$$

(1) J. J. Brennan and J. A. Pask: J. Amer. Ceram. Soc. 51(1968), 569.

(2) K. Prabriputaloong and M. R. Piggott: Surface Science, $44(1974), 585$.

（3）宮原広郁, 大谷 潤, 森 信幸, 大城桂作：日本金属学 会誌, $\mathbf{5 6}$ (1992), 1056.

(4) R. N. Wenzel: Ind. Eng. Chem., 28(1936), 988.

（5）森信幸, 浮田求, 大城桂作:日本金属学会誌, $\mathbf{5 5}(1991), 820$.

（6）森 信幸, 空野博明, 北原 晃, 大城桂作, 松田公扶: 日本金属学会誌, 47(1983), 1132.

（7）長 隆郎, 沖 猛雄：日本金属学会誌, 51(1987), 1209

(8) 森 信幸, 松尾 識, 大城桂作, 松田公扶：日本金属学 会誌, 51(1987), 240 .

(9) F. Bashforth and J. C. Adams: An Attempt to Test the The ories of Capillary Action, Cambridge Univ. Press, (1883).

（10）たとえば嘉納秀明：システムの最適化理諭と最適化，コ ロナ社, (1988), 82.

（11）高山透， 日野谷重晴：日本金属学会会報，31(1992), 687.

（12）た之党ば村松宏司：真空冶金，真空技術講座 9，林 主税監修，(1965)，62.

（13）吉見直人，中江秀雄，藤井英俊：日本金属学会誌, $\mathbf{5 2}(1988), 1179$.

(14) S. Glasstone: Thermodynamics for Chemist, Van Nostland, (1947), 244.

(15) Lang. G: ALUMINIUM, 49(1973), 231.

(16) Lang. G. ALUMINIUM, 50(1974), 731.

(17) D. T. Livey and P. Murray: J. Amer. Ceram. Soc., 39 (1956), 363.

(18) S. K. Rhee: J. Amer. Ceram. Soc., 55 (1972), 300.

(19) T. Young: Phil. Trans. Roy. Soc., $95(1805), 65$.

(20) J. E. McDonald and J. G. Eberhart: Trans. Met. Soc. AIME, 233(1965), 512 .

（21）野城 清, 荻野和已：日本金属学会誌，16(1990)85.

(22) S. Newman: J. Colloid and Interface Science, 26 (1968), 209.

(23) T. M. French and G. A. Somorjai: J. Phys. Chem., 74(1970), 2489.

(24) C. G. Levi, G. J. Abbaschian and R. Mehrabian: Metall. Trans., 9A(1978), 697.

(25) A. Munitz, M. Metzger and R. Mehrabian: Metall. Trans., 10A (1979), 1491.

(26) I. Jin and D. J. Lloyd: Proc. of 2nd International Conference on Cast Metal Matrix Composites, Tuscaloosa, Alabama, (1993), 288.

（27）後藤和弘：日本金属学会編「拡散の基礎と応用」, (1984), 41 .

(28) 大石行理, 安藤 健 : 日本化学会編「固体の関与する無 機化学反応」, (1975), 31. 